\title{
Dietary proteins and IGF I levels in preterm infants: determinants of growth, body composition, and neurodevelopment
}

\author{
Dana F.J. Yumani' ${ }^{1}$ Harrie N. Lafeber ${ }^{1}$ and Mirjam M. van Weissenbruch ${ }^{1}$
}

It has been demonstrated that a high-protein diet in preterm born infants during the first weeks of life may enable a growth rate equal to that seen in utero and may also result in a better long-term neurodevelopmental outcome. This diet may limit immediate postnatal growth retardation and may hence lower the risk of increased fat deposition after birth leading to the metabolic syndrome in later life. Insulin-like growth factor I (IGF I) has proven to play an important role in early postnatal growth of preterm infants, but also seems to have a persisting influence on body composition in childhood. Furthermore, increased IGF I concentrations in preterm infants have been associated with improved neurodevelopmental outcome. This review will elaborate on the role of dietary proteins and IGF I on growth, body composition, and neurodevelopment of preterm infants. Possible causal pathways will be explored and areas for future research will be proposed.

$\mathbf{P}$ ostnatal growth restriction is a major problem faced in the care for preterm infants. At $36 \mathrm{wk}$ postmenstrual age, $91 \%$ of all preterm infants show postnatal growth restriction (weight $\leq 1.3 \mathrm{SD}$ ) (1). At term age, $\sim 30 \%$ of infants are reported to still be growth restricted (2). As survival rates of preterm infants with an increasingly younger gestational age rise, we are subsequently confronted with the long-term sequelae of preterm birth. At 11 y of age, $40 \%$ of children born before $26 \mathrm{wk}$ of gestation have been reported to have serious neurocognitive impairment and moderate to severe impairment of neuromotor function, vision and hearing was reported in respectively 10,9 , and $2 \%$ of cases (3). Preterm birth and postnatal growth restriction have both been associated with impaired neurodevelopmental outcome (4). However, Franz et al. found that only a small percentage of the variability, roughly $3 \%$, of the mental processing composite score was explained by growth (5). There might be a common factor leading to both poor growth and poor neurodevelopment, e.g., a poor nutritional status or major neonatal morbidities. Nonetheless, several studies suggest that there might be independent pathways $(5,6)$. Either way, these poor outcomes warrant an intervention. Furthermore, preterm infants are prone to develop risk factors for the onset of the metabolic syndrome. They are reported to have lower insulin sensitivity, increased blood pressure and increased fat mass in childhood and young adulthood (7-9). Nutritional interventions in these infants have been found to influence the development of risk factors for the metabolic syndrome (10). Hence, neonatologists are challenged to compose and administer a diet which limits postnatal growth restriction; yet with caution to also limit the development of risk factors for the onset of the metabolic syndrome.

Dietary factors, endocrine function, and the simple immaturity of organ systems are entangled in the endeavor to optimize postnatal growth and metabolic programming. Dietary proteins are essential in enabling a growth rate similar to intrauterine growth (11). Nevertheless, the balance between proteins and other nutrients are essential to understand how growth and body composition in preterm infants can be optimized. Insulin-like growth factors (IGF) are a key in the endocrine regulation of growth. Notably, IGF I has an anabolic and mitogenic effect which is crucial for symmetric growth due to the presence of the IGF I receptor in multiple cell types and tissues. Moreover, IGF I synthesis in multiple peripheral tissues causes it to function as an auto- and paracrine factor which does not merely influence growth, but also organ functioning. IGF I's possible influence on neurodevelopmental outcome may be potentiated through its trophic effect or through altering the functioning of the central nervous system.

In this review, we aim to explore the possible pathways relating neonatal dietary protein intake and IGF I levels to growth, body composition, and neurodevelopmental outcome in infancy, childhood, and young adulthood.

\section{IGF I REGULATION}

IGF I is a small polypeptide which is mainly synthesized in the liver. It stimulates cell division, cell growth, cell motility, glucose uptake, and protein synthesis. Furthermore, IGF I inhibits apoptosis. Prenatally it is secreted into the blood under control of insulin. Postnatally growth hormone $(\mathrm{GH})$ gradually takes over this role. In addition, malnutrition and 
hypothyroidism negatively influence IGF I plasma levels. IGF I is also synthesized in multiple peripheral tissues, e.g., kidney, bone, and muscle, where it is released under control of GH and local factors. 99\% of IGF I in plasma is bound to high affinity IGF binding proteins which control IGF I transportation and distribution (12).

\section{THE ROLE OF IGF I IN GROWTH AND BODY COMPOSITION}

Fetal IGF I levels gradually increase during pregnancy to reach $\sim 46-90 \mathrm{ng} / \mathrm{ml}$ at term age (13). After preterm birth, IGF I levels slowly increase (14). Meanwhile, infants born at term show a quick surge in IGF-I levels (15). Figure 1 illustrates postnatal IGF I levels in preterm and term infants.

In preterm infants, IGF I levels at birth are positively correlated with birth weight (16). Until term age, these infants IGF I levels' are also positively correlated with their preceding as well as their subsequent weight gain, indicating higher previous as well as higher subsequent growth rate in those infants with higher IGF I levels (14).

However, after term age contradictory findings have been reported. Several studies observed IGF I levels to positively correlate with current growth parameters and preceding growth velocity in preterm as well as healthy term infants (1720). In contrast, findings concerning the correlation between IGF I levels and subsequent growth velocity are inconclusive (Table 1). Hypothesizing these findings might reflect that after term age a turning point occurs. At this point, infants with the lowest IGF I levels and thus the poorest previous growth may tend to show accelerated growth. This hypothesis would be in line with the negative correlation between IGF I and subsequent growth velocity found in the above stated studies: infants with the lowest IGF I levels had the highest subsequent

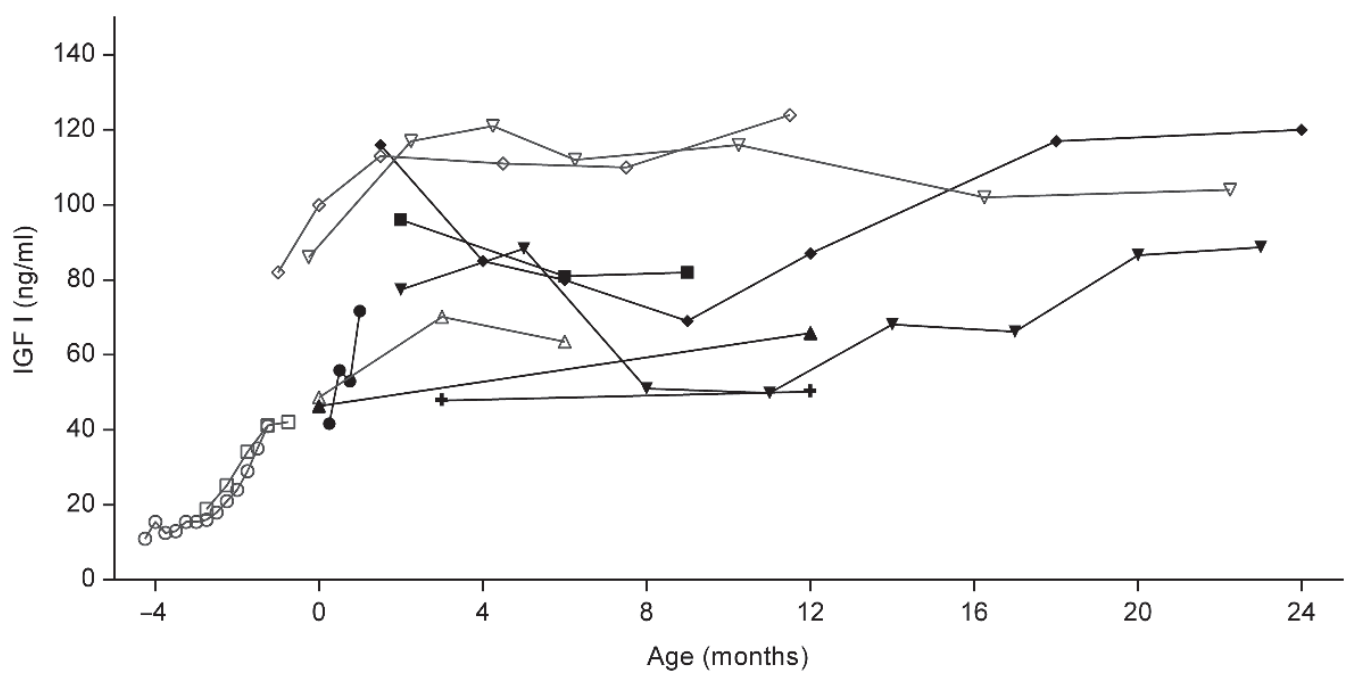

Figure 1 Postnatal insulin-like growth factor I (IGF I) levels in preterm and term infants. Preterm infants: Hansen-Pupp (open circle) (14), Ohkawa (open square) (80), van de Lagemaat (open triangle) (18), Giapros (open diamond) (20), Wang (open, inverted triangle) (81). Term infants: Iniguez (closed triangle) (82), Kurtoglu (closed circle) (15), Wang (closed diamond) (81), Larnkjaer (closed square) (37), Hyun (closed, inverted triangle) (83), and Ong (plus) (28).

Table 1 Associations between IGF I and growth

\begin{tabular}{|c|c|c|c|c|c|c|}
\hline & $\begin{array}{c}\text { van de } \\
\text { Lagemaat (18) }\end{array}$ & $\begin{array}{c}\text { van de } \\
\text { Lagemaat (18) }\end{array}$ & Giapros (20) & Chellakooty (17) & Ong (28) & Socha (19) \\
\hline Study population & Very preterm infants & $\begin{array}{l}\text { Very preterm } \\
\text { infants }\end{array}$ & Late preterm infants & $\begin{array}{l}\text { Healthy term } \\
\text { infants }\end{array}$ & $\begin{array}{l}\text { Healthy term } \\
\text { infants }\end{array}$ & $\begin{array}{l}\text { Healthy term } \\
\text { infants }\end{array}$ \\
\hline Timing IGF I blood draw & Term age & $3 \mathrm{mo}$ & $6 \mathrm{wk}, 3$ and $6 \mathrm{mo}^{\mathrm{a}}$ & $3 \mathrm{mo}$ & $3 \mathrm{mo}$ & $6 \mathrm{mo}$ \\
\hline \multirow[t]{2}{*}{$\begin{array}{l}\text { IGF I and previous } \\
\text { growth velocity }\end{array}$} & $\begin{array}{l}\uparrow \Delta \text { weight SDS } \\
\text { (birth to term age) }\end{array}$ & $\begin{array}{l}\uparrow \Delta \text { weight SDS } \\
\text { (birth to } 3 \mathrm{mo}^{\text {b) }}\end{array}$ & $\uparrow$ weight $^{c}$ & $\begin{array}{l}\uparrow \Delta \text { weight SDS } \\
\text { (birth to } 3 \mathrm{mo} \text { ) }\end{array}$ & Not reported & $\begin{array}{l}\uparrow \triangle \mathrm{WFL} \text { SDS } \\
\text { (birth to } 6 \mathrm{mo} \text { ) }\end{array}$ \\
\hline & $\begin{array}{l}\uparrow \Delta \text { length SDS } \\
\text { (birth to term age) }\end{array}$ & 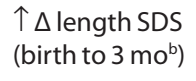 & $\uparrow$ length $^{c}$ & $\begin{array}{l}\uparrow \Delta \text { length SDS } \\
\text { (birth to } 3 \mathrm{mo} \text { ) }\end{array}$ & & \\
\hline IGF I and current growth & $\begin{array}{l}\uparrow \text { weight and } \\
\text { length SDS }\end{array}$ & $\begin{array}{l}\uparrow \text { weight and } \\
\text { length SDS }\end{array}$ & $\uparrow$ weight and length SDS & $\uparrow$ weight; $\rightarrow$ length & $\begin{array}{l}\text { 个 weight; } \\
\rightarrow \text { length }\end{array}$ & $\uparrow W F L S D S$ \\
\hline \multirow[t]{2}{*}{$\begin{array}{l}\text { IGF I and subsequent } \\
\text { growth velocity }\end{array}$} & $\begin{array}{l}\downarrow \Delta \text { weight SDS } \\
\text { (term age to } 6 \mathrm{mo}^{\mathrm{b}} \text { ) }\end{array}$ & $\begin{array}{l}\rightarrow \Delta \text { weight } \\
\text { SDS }\left(3-6 \mathrm{mo}^{\mathrm{b}}\right)\end{array}$ & $\begin{array}{l}\rightarrow \text { (growth parameters } \\
\text { not specified) }\end{array}$ & $\begin{array}{l}\downarrow \Delta \text { weight SDS } \\
(3-18 \mathrm{mo})\end{array}$ & $\begin{array}{l}\rightarrow \Delta \text { weight } \\
(3-12 \mathrm{mo})\end{array}$ & $\begin{array}{l}\rightarrow \Delta \text { WFL SDS } \\
(6-12 \mathrm{mo})\end{array}$ \\
\hline & 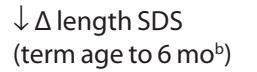 & $\begin{array}{l}\rightarrow \Delta \text { length } \\
\text { SDS }\left(3-6 \mathrm{mo}^{\mathrm{b}}\right)\end{array}$ & & $\begin{array}{l}\rightarrow \Delta \text { length SDS } \\
(3-18 \mathrm{mo})\end{array}$ & $\begin{array}{l}\uparrow \Delta \text { length } \\
(3-12 \mathrm{mo})\end{array}$ & \\
\hline
\end{tabular}

IGFI, insulin-like growth factor I; SDS, standard deviation score; WFL, weight-for-length. $\uparrow=$ positive correlation; $\downarrow=$ negative correlation; $\rightarrow=$ no correlation; $\Delta=$ gain.

${ }^{a}$ Chronological age. ${ }^{b}$ Corrected age. ${ }^{C H i g h e r ~ I G F ~ I ~ l e v e l s ~ i n ~ i n f a n t s ~ w i t h ~ a c c e l e r a t e d ~ p r e v i o u s ~ w e i g h t ~ a n d ~ l e n g t h ~ g a i n ~(a ~ d i f f e r e n c e ~ o f ~ m o r e ~ t h a n ~} 0.67$ SDS between two study points). 


\section{Review $\mid$ Yumaniet al.}

growth velocity. Less comorbidity in preterm infants after term age might create a less stressful environment in which catch-up growth could occur, i.e., an increased growth rate compared to the infant's previous growth rate, enabling the infant to reach a body size comparable to that of healthy infants at a corresponding age. Also, further maturation of the neuroendocrine axes and target organs may improve feedback mechanisms and thus optimize growth control. Hypothesizing more into detail, eventually a point may be reached where growth velocity is fixed regardless of the previous growth pattern. This would then correspond with the absence of a correlation between IGF I levels and subsequent growth. At this point, the neuroendocrine axes and target organs may be completely programmed setting the growth rate at a fixed point.

Concluding these diverse associations may possibly illustrate a regulatory effect to direct growth towards the mean. For IGF I to function optimally, i.e., to enable growth to the full potential of each individual, certain conditions are paramount. The neuroendocrine axes and target organs need to be matured to such an extent that feedback mechanisms can reliably control growth, i.e., correct too slow as well as too fast growth. Furthermore, the environment needs to reinforce a steady growth rate; meaning that sufficient nourishment needs to be available and stressful factors, such as comorbidities, should be limited. Hypothesizing after term age there may be an optimal combination of these conditions, creating a window of opportunity to catch up in growth. In comparison, in children who are adopted from impoverished and stressful situations, growth restriction occurs. When they are placed in a more nurturing environment through adoption catch-up growth is observed. In a study by Miller et al., adopted children with the lowest IGF I had 4.9 times higher odds (95\% CI: 1.122.9) of showing catch-up growth in height than children with the highest IGF I (mean age at adoption $20.1 \mathrm{mo} \pm 9.8$ ) (21).

Simplified, preterm infants show three growth patterns: small size at birth and persistent small size at term age (small for gestational age infants), appropriate size at birth but small size at term age (appropriate for gestational age infants with postnatal growth restriction) and appropriate size at birth and appropriate size at term age (appropriate for gestational age infants without postnatal growth restriction). In analogy with children following adoption, it is hypothesized that infants small at term age come into a less stressful period after term age which enables them to catch up in growth. Indeed some infants, but not all, show "catch-up" growth. The majority of this "catch-up" growth occurs in the first 6-12 mo of life (22). However there is a concern that rapid growth leads to an unfavorable metabolic and cardiovascular outcome in later life. Indeed, De Jong et al. found increased length gain between 6 and 12 mo corrected age and weight gain between term and 2 y corrected age to be associated with increased systolic blood pressure at 2 y corrected age (23). In addition, Singhal et al. found a poorer endothelial function in preterm born adolescents with the highest rate of weight gain in the first $2 \mathrm{wk}$ after birth (24). In comparison, in term born young adults, rapid weight gain in the first 3 mo of life has also been associated with decreased insulin sensitivity, a higher percentage of body fat and more central adiposity (25). Moreover, Hovi et $a l$. demonstrated that a decrease in weight $\mathrm{z}$-score from birth to term was associated with a higher blood pressure in adulthood. However, this association did not remain significant after adjusting for gestational age at birth (26). Nonetheless, a recent review by Lapillonne and Griffin on the effect of postnatal growth on metabolic and cardiovascular outcomes in preterm born adults concluded that, in contrast to growth during late infancy and childhood, growth up to $1 \mathrm{y}$ was not associated with adult blood pressure, glucose tolerance or lipid profile (27). However, the studies described in the review were heterogenic and did not all take a possible confounding effect of nutrition and small vs. appropriate for gestational age into account. Therefore, the concern of a possible negative impact of initial growth restriction and subsequent catch-up growth expressed through several studies cannot yet be disregarded. Currently, there is no full understanding of which infants will and which ones will not completely "catch-up." As in children following adoption, one might hypothesize that infants with the lowest IGF I level in the early post term period are the ones who will show catch-up growth. However, to our knowledge as of yet, there is no evidence supporting this hypothesis in preterm infants. This hypothesis regarding catch-up growth might depend on the plasticity of the neuroendocrine axes and target organs. In certain infants, intrauterine or early-life insults may completely program the neuroendocrine axes and target organs. However, if there is some plasticity left, alteration of the growth rate may occur. This might further depend on environmental factors, e.g., lack of comorbidities and sufficient nourishment, in combination with the genetic make-up of the infant.

Remarkably, in term infants several studies did not find a correlation between IGF I and subsequent weight gain, while they did find a positive correlation with subsequent length gain. Thus, higher IGF I levels were associated with a subsequent lower BMI $(28,29)$. This might imply that high IGF I levels protect against adiposity. Growth-restricted and preterm infants would then be at increased risk of developing obesity, because of their presumably low IGF I levels. Indeed, in small for gestational age very low birth weight infants IGF I levels up to 3 mo corrected age have been positively associated with lean mass at 2 y (30). Moreover, preterms were found to have increased fat mass and decreased lean mass in childhood (9). However, a recent meta-analysis could not confirm that this trend persists into adulthood (31).

Yet it remains to be clarified whether IGF I is primarily associated with change in height or is equally related to change in weight. Surely, IGF I is involved in bone accretion, but it is also implied in adipogenesis $(32,33)$. Indeed Stigson et al. found that higher IGF I levels at a postmenstrual age of 30$32 \mathrm{wk}$ were associated with increased bone mass (9). Also, a trend of higher IGF I levels was found in preterm infants who increased in bone strength compared to preterm infants with a decrease in bone strength measured by bone speed of sound (34). In line with these findings, preterm infants born small for 


\section{Dietary proteins and IGF I in preterms}

gestational age had decreased bone accretion at 6 mo corrected age. In addition, 20 y olds who were born preterm, especially those small for gestational age, had decreased bone mineral density and were shorter compared to term controls $(35,36)$. Interestingly, however, others found normal bone mass in 4-yold children who were born preterm (9). As stated by Stigson et al., osteoblasts as well as adipocytes are derived from the same progenitor cells and the IGF system could be important in directing the differentiation to either adipocytes or osteoblasts (9). It may well be that states with low IGF I levels, such as critical illness, nutrient restriction and extreme prematurity, stimulate differentiation towards adipogenesis as a mechanism to ensure an easily accessible energy store, in this relatively catabolic state, as compared to anabolic states with high IGF I levels where sustainable growth through bone formation might be obtained.

Nevertheless, the role of IGF I in growth, body composition, and development of the metabolic syndrome remains complex. For instance, lower IGF I levels in infancy have been associated with higher IGF I levels in later life (37). This suggests that events in early life can program IGF I and possibly metabolic outcomes in later life. However, low as well as high IGF I levels in adulthood have been associated with the metabolic syndrome and cardiovascular disease (38). Therefore, it is difficult to give a clear-cut view of the role of IGF I alone in growth, body composition, and the development of the metabolic syndrome.

\section{THE ROLE OF IGF I IN NEURODEVELOPMENT}

In clinical studies, brain and cranial growth have been associated with subsequent neurodevelopment $(5,39)$. A polymorphism in the IGF I promotor gene, which is known to regulate serum IGF I levels, has been related with slower cranial growth from birth until $5 \mathrm{y}$ of age (40). Moreover, Hansen-Pupp et al. found IGF I levels to correlate with brain volumes while there was no association with cerebral spinal fluid volume. The authors hypothesize that this could imply that IGF I does not limit atrophy secondary to brain damage, but rather stimulates brain growth (41). In premature infants, a higher rate of increase of IGF I until $35 \mathrm{wk}$ postmenstrual age has directly been related to a better neurodevelopmental outcome at $2 \mathrm{y}$ of age (39). In line with that, Okuma et al. found that IGF I levels were associated with white matter organization (42). Interestingly, mean IGF I concentration was positively correlated to neurodevelopmental outcome during a period, from 30 to $35 \mathrm{wk}$ postmenstrual age, when a surge in IGF I levels occurred and infants started growing after a phase of postnatal growth restriction $(14,39)$. This may suggest that IGF I has to reach a certain level before it can enhance neurodevelopmental outcome. Even so, the premature disruption of the maternalplacental-fetal unit alters more neuroendocrine factors than merely IGF I, which also influences the final neurodevelopmental outcome.

In analogy with the development of retinopathy of prematurity, the sudden decrease in IGF I at birth could cause stagnation in vascular growth. It is hypothesized that the surge in IGF I might lead to neovascularization with abnormal vessel formation, which could cause intracranial hemorrhage and consequently influence neurodevelopmental outcome. In experimental studies it has been suggested that IGF I may limit damage after hypoxic-ischemic brain injury and inflammation $(43,44)$. Moreover, mice treated with IGF I seemed to have increased proliferation of immature oligodendrocytes, while the number of mature oligodendrocytes remained the same. This was hypothesized to possibly promote myelination at later stages when the immature oligodendrocytes mature and start myelinating (45). In addition, lipopolysaccharide induced brain inflammation in a mouse model led to lower IGF I levels and impaired myelination in the subcortical white matter (46). However, in a rat periventricular leukomalacia model, it was demonstrated that exogenous IGF I limited lipopolysaccharide induced damage at a low dose, while it increased damage at higher doses (47). Recently, IGF I administration has been investigated in a phase I study in preterm infants and showed to effectively increase IGF I levels without any adverse events (48). In the near future, this might offer a therapeutic intervention potentially improving neurodevelopment as well as growth and body composition.

\section{THE ROLE OF DIETARY PROTEINS IN GROWTH AND BODY COMPOSITION}

In the first weeks of life preterm infants, almost universally accumulate a protein deficit and show postnatal growth restriction. In an attempt to achieve an intrauterine-like growth rate, neonatologists are challenged to administer the right composition of amino acids and the optimal amount of proteins, combined with sufficient fatty acids and carbohydrates, to optimize nitrogen accretion. Currently, the recommended range of protein intake for preterm infants is $3.5-4.5 \mathrm{~g} / \mathrm{kg} / \mathrm{d}$ (49). Over the past few years, increasing amounts of parenteral amino acids have been administered to preterm infants showing a consistent increase in protein balance. Recent nutritional studies have actually demonstrated that by administering high dose parenteral amino acids current recommendations for protein intake and intrauterine-like growth rates can be achieved, nutritional deficits can drastically be reduced and postnatal growth restriction can in part be prevented (Figure 2) (11). It is recognized that high and early introduction of proteins can limit the initial postnatal weight loss (50). By reducing initial weight loss, the tendency for rapid "catch-up" growth might be reduced, which may lead to more favorable metabolic programming. Indeed, low protein levels are associated with low IGF I levels (51), which in turn is associated with fat mass accretion in childhood (30).

However, after the initial period of weight loss, in which parenteral feeding is the primary source of nutrition, growth sets in. When growth occurs, protein requirements can be re-evaluated and slowly tapered off to reach $2-3 \mathrm{~g} / \mathrm{kg} / \mathrm{d}$ at term age (52). Caution is warranted to maintain an appropriate protein intake when transitioning from parenteral to enteral nutrition. However, enteral and parenteral protein intake might not be similar. For instance, bypassing the enteral route is likely to 
a

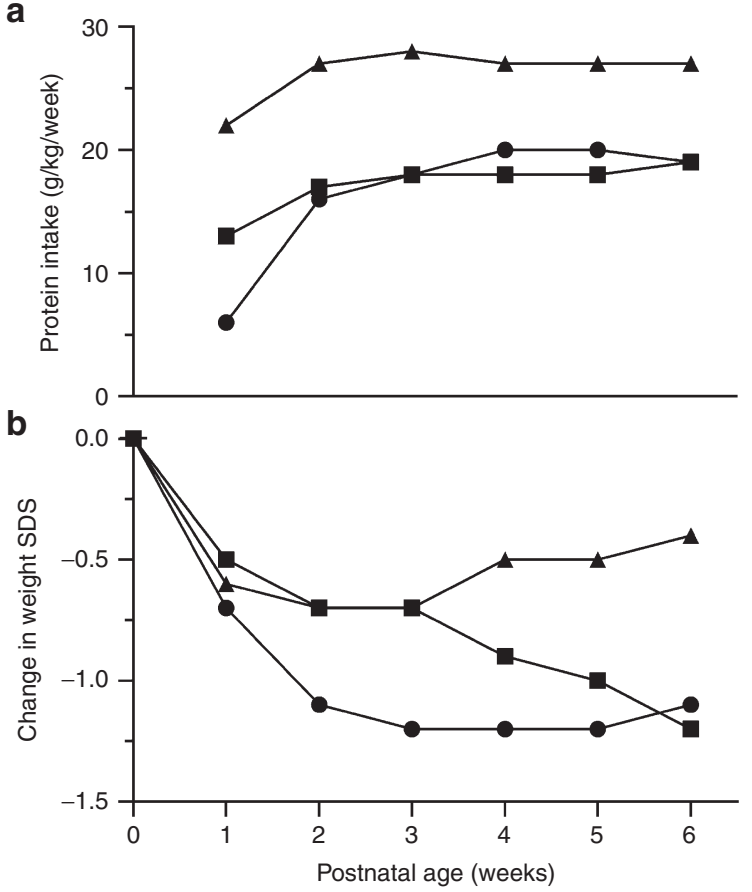

Figure 2 Protein intake and change in weight z-sore. (a) Protein intake and (b) change in weight z-score in the first 6 wk of life achieved by standard practice in our neonatal intensive care unit in Amsterdam, The Netherlands (square) (M. Krikke, unpublished data) compared with that reported by Embleton (circle) (84) before current ESPGHAN guidelines and Senterre (triangle) (85) using current ESPGHAN guidelines.

lower the systemic availability of certain amino acids which are metabolized from other amino acids in the intestine and/ or liver (50).

In spite of several studies which did not find an increased growth after augmenting protein intake $(53,54)$, most studies demonstrate that increased protein intake in the neonatal period positively influences growth up to term age (55-59). These studies report improved absolute and standardized measures of weight, length and head circumference as well as an increased growth velocity. No intolerance of high-protein diets has been reported $(52,60)$ and glycaemic control might actually be improved with a high protein intake $(53,54)$. However, protein intake in the neonatal period will not necessarily have an impact on growth indices in childhood (59). A high protein intake in the in-hospital as well as in the post discharge period seems to decrease fat mass and increase lean mass up to 6 mo corrected age (61-63). Whether this trend persists into childhood is not known. Using bone transmission time, Scattolin et al. found protein intake to positively correlate with bone mineral status at 36 wk postmenstrual age (60). However, Fewtrell was unable to correlate protein intake in infancy with peak bone mass or bone turnover in young adulthood (36). Thus, a persisting beneficial effect of early protein intake on growth and body composition in later life has not yet been confirmed.

Even though protein is vital to optimize growth, its relation to other nutrient components and the administration of specific amino acids are equally important. Indeed, Mcleod et al. demonstrated that an increased protein/energy ratio reduced adipose tissue accretion as compared to muscle accretion. Surely, energy from another source than protein itself is necessary for net protein gain. However, when non-protein caloric intake surpasses $60 \mathrm{kcal} / \mathrm{kg} / \mathrm{d}$, protein intake itself is the primary determinant of protein gain. Nevertheless, it should be questioned to which level the protein/energy ratio should be increased. The ESPGHAN committee on nutrition recommends a ratio of 3.2 to $4.1 \mathrm{~g}$ protein/100 $\mathrm{kcal}$ (49). Yet there is a need of supportive evidence as to which ratio should be maintained at specific points in time. Several studies found that when preterm infants were on complete enteral nutrition increasing the protein/energy ratio above $3 \mathrm{~g}$ protein $/ 100 \mathrm{kcal}$ did not improve fat free mass accretion compared to a ratio of $2.7-2.8 \mathrm{~g}$ protein $/ 100 \mathrm{kcal}(61,64)$. To our knowledge studies conducted so far have not assessed the effects on body composition of various protein/energy ratios in the first $2 \mathrm{wk}$ of life. Because preterm infants have limited ability to synthesize certain non-essential amino acids those amino acids become conditionally essential. Some have proposed that the addition of these so called semi-essential amino acids to the diet of preterm infants will improve growth. Cysteine for example, has been implied to be one of the key factors which potentiate the trophic effect of high-protein diets (65).

THE ROLE OF DIETARY PROTEINS IN NEURODEVELOPMENT During hospitalization increased protein intake improves head growth in preterm infants $(66,67)$. Even so total energy and lipid intake also have been positively correlated with head growth $(67,68)$. Nonetheless, Hansen-Pupp et al. could not associate protein and caloric intake with brain volumes (39) and in several studies protein-enriched nutrition failed to improve neurodevelopmental outcome up to 18 mo corrected age $(53,66,69,70)$. Macro- and microstructural brain analyses could not be correlated to intake of protein or other nutritional components either (42). Yet, two studies by Stephens et al. and Cormack et al. showed that protein intake in the first weeks of life was positively correlated with the cognitive and motor score on the Bayley Scales of Infant Development (71,72). In addition, Biasini et al. found that increased protein intake in extremely low birth weight infants improved performance and hearing/language scores on the Griffith Development Mental Score at 3 and 12 mo corrected age (73). Moreover, increased fat free mass, which is claimed to reflect protein accretion, was associated with faster neuronal processing at 4 mo corrected age (74). Also, perinatal protein restriction in mice altered the intracerebral dopamine circuit which caused altered rewardprocessing and hyperactivity (75). The authors suggest that this could possibly be translated to adverse neurodevelopmental outcome, such as ADHD, in growth-restricted infants. Furthermore, in preterm infants who were fed a high-nutrient diet larger caudate volumes and higher verbal IQ were found in adolescence (76).

So far, pathways explaining the association between neurodevelopment and protein intake are still speculative. Compared to other nutrient components the unique feature of protein might just lie in the alteration of neuronal processing. Perhaps 


\section{Dietary proteins and IGF I in preterms $\quad$ Review}

that the underlying mechanism works through increased neurotransmitter- and receptor synthesis. Indeed, increased lactalbumin intake in rats increased cortex tryptophan. Nevertheless, casein had a negative effect on tryptophan (77). Also, de Kieviet et al. found an increased oral glutamine intake to be associated with increased volumes of white matter, hippocampus, and brain stem in very preterm children at school age (78). Since glutamine has been shown to reduce the number of serious infections in very preterm children, they hypothesized that increased glutamine intake indirectly influences neurodevelopment by reducing infections in the neonatal period.

\section{IGF I AND DIETARY PROTEINS}

As stated earlier, IGF I levels are related to nutritional intake. Socha et al. demonstrated that infants fed high-protein followup formula had higher IGF I levels than those fed low-protein follow-up formula (19). Moreover, a minimal caloric as well as a minimal protein intake has to be reached to maintain normal IGF I levels (12). Furthermore, there is a strong negative effect of breast milk on IGF I levels. Next to the lower protein content other, yet to be determined, factors might play a role in establishing this effect (79). Given the reciprocal relation between IGF I and nutrition, nutritional interventions might be the key factor in improving growth, body composition and neurodevelopmental outcome of preterm infants. Interestingly, Hansen-Pupp et al. found that IGF I and nutritional intake only correlated after a postmenstrual age of $30 \mathrm{wk}$ (14). The timing of a nutritional intervention may therefore be crucial for the sustainability of its effect.

\section{CONCLUSIONS}

Altogether, preterm and small for gestational age infants are at risk for impaired growth and a suboptimal body composition, making them prone to risk factors for the metabolic syndrome. Low early postnatal IGF I levels seem to be at the origin of this problem. Increased early dietary protein intake has shown to improve growth and body composition in infancy. However, it is yet to be elucidated whether this trend persists in later life, thus calling for long-term follow-up studies.

Higher IGF I levels and increased dietary protein intake have been found to also improve neurodevelopmental outcome of preterm infants. Evidence supports a trophic role of IGF I in the development of the central nervous system. So far, signs of a direct mechanism which limits damage from hypoxicischemic and inflammatory insults have only been found in experimental studies. However, it is plausible that improved neuronal processing due to higher IGF I levels and an increased dietary protein intake may play a role in preterm infants.

Since IGF I levels are related to dietary protein intake it would be valuable to investigate whether a nutritional intervention could improve the long-term outcome of preterm infants by optimizing IGF I levels as well as optimally using the potential of IGF I. It may be argued whether initial IGF I levels are sufficient or should be further increased by increasing nutrient intake in the early postnatal period. On the other hand, nutrient intake might have to be reduced once IGF I reaches the level where it's trophic and neurodevelopment enhancing potential becomes effective, creating a more favorable setting for further development. Moreover, assessment of the optimal protein/energy ratio in this period may be a key to improve metabolic programming and studies on specific amino acids could ameliorate dietary advices. In addition, it has to be questioned whether IGF I administration to preterm infants could offer a potential future therapeutic intervention. Altogether, the above illustrates the important gap of knowledge in potential causal pathways between dietary protein intake, IGF I levels and long-term outcomes of preterm infants that needs to be explored in future research.

Disclosure: The authors declare no conflict of interest.

\section{REFERENCES}

1. Fanaroff AA, Stoll BJ, Wright LL, et al.; NICHD Neonatal Research Network. Trends in neonatal morbidity and mortality for very low birthweight infants. Am J Obstet Gynecol 2007;196:147.e1-8.

2. Leppänen M, Lapinleimu H, Lind A, et al.; PIPARI Study Group. Antenatal and postnatal growth and 5-year cognitive outcome in very preterm infants. Pediatrics 2014;133:63-70.

3. Johnson S, Fawke J, Hennessy E, et al. Neurodevelopmental disability through 11 years of age in children born before 26 weeks of gestation. Pediatrics 2009;124:e249-57.

4. Cooke RW, Foulder-Hughes L. Growth impairment in the very preterm and cognitive and motor performance at 7 years. Arch Dis Child 2003;88:482-7.

5. Franz AR, Pohlandt F, Bode $\mathrm{H}$, et al. Intrauterine, early neonatal, and postdischarge growth and neurodevelopmental outcome at 5.4 years in extremely preterm infants after intensive neonatal nutritional support. Pediatrics 2009;123:e101-9.

6. Ehrenkranz RA, Dusick AM, Vohr BR, Wright LL, Wrage LA, Poole WK. Growth in the neonatal intensive care unit influences neurodevelopmental and growth outcomes of extremely low birth weight infants. Pediatrics 2006;117:1253-61.

7. Rotteveel J, van Weissenbruch MM, Twisk JW, Delemarre-Van de Waal HA. Infant and childhood growth patterns, insulin sensitivity, and blood pressure in prematurely born young adults. Pediatrics 2008;122:313-21.

8. Kerkhof GF, Breukhoven PE, Leunissen RW, Willemsen RH, HokkenKoelega AC. Does preterm birth influence cardiovascular risk in early adulthood? J Pediatr 2012;161:390-396.e1.

9. Stigson L, Kistner A, Sigurdsson J, et al. Bone and fat mass in relation to postnatal levels of insulin-like growth factors in prematurely born children at $4 \mathrm{y}$ of age. Pediatr Res 2014;75:544-50.

10. Lafeber HN, van de Lagemaat M, Rotteveel J, van Weissenbruch M. Timing of nutritional interventions in very-low-birth-weight infants: optimal neurodevelopment compared with the onset of the metabolic syndrome. Am J Clin Nutr 2013;98:556S-60S.

11. Rigo J, Senterre T. Intrauterine-like growth rates can be achieved with premixed parenteral nutrition solution in preterm infants. J Nutr 2013;143(12 Suppl):2066S-70S.

12. Clemmons DR. Physiology of insuline-like growth factor I. (http://www. uptodate.com/contents/physiology-of-insulin-like-growth-factor-i.) Accessed 5 February 2014.

13. Hawkes CP, Grimberg A. Measuring growth hormone and insulinlike growth factor-I in infants: what is normal? Pediatr Endocrinol Rev 2013;11:126-46.

14. Hansen-Pupp I, Löfqvist C, Polberger S, et al. Influence of insulin-like growth factor I and nutrition during phases of postnatal growth in very preterm infants. Pediatr Res 2011;69(5 Pt 1):448-53.

15. Kurtoglu S, Kondolot M, Mazicioglu MM, Hatipoglu N, Akin MA, Akyildiz B. Growth hormone, insulin like growth factor-1, and insulin-like growth factor-binding protein-3 levels in the neonatal period: a preliminary study. J Pediatr Endocrinol Metab 2010;23:885-9. 
16. Martos-Moreno GA, Barrios V, Sáenz de Pipaón M, et al. Influence of prematurity and growth restriction on the adipokine profile, IGF1, and ghrelin levels in cord blood: relationship with glucose metabolism. Eur J Endocrinol 2009;161:381-9.

17. Chellakooty M, Juul A, Boisen KA, et al. A prospective study of serum insulin-like growth factor I (IGF-I) and IGF-binding protein-3 in 942 healthy infants: associations with birth weight, gender, growth velocity, and breastfeeding. J Clin Endocrinol Metab 2006;91:820-6.

18. van de Lagemaat M, Rotteveel J, Heijboer AC, Lafeber HN, van Weissenbruch MM. Growth in preterm infants until six months postterm: the role of insulin and IGF-I. Horm Res Paediatr 2013;80:92-9.

19. Socha P, Grote V, Gruszfeld D, et al.; European Childhood Obesity Trial Study Group. Milk protein intake, the metabolic-endocrine response, and growth in infancy: data from a randomized clinical trial. Am J Clin Nutr 2011;94(6 Suppl):1776S-84S.

20. Giapros VI, Schiza V, Challa AS, Pantou C, Theocharis PD, Andronikou SK. Serum insulin-like growth factor I (IGF-I), IGF-binding proteins- 1 and -3 , and postnatal growth of late preterm infants. Horm Metab Res 2012;44:845-50.

21. Miller BS, Kroupina MG, Mason P, et al. Determinants of catch-up growth in international adoptees from eastern europe. Int J Pediatr Endocrinol 2010;2010:107252.

22. Ong KK. Catch-up growth in small for gestational age babies: good or bad? Curr Opin Endocrinol Diabetes Obes 2007;14:30-4.

23. de Jong M, Lafeber HN, Cranendonk A, van Weissenbruch MM. Components of the metabolic syndrome in early childhood in very-lowbirth-weight infants. Horm Res Paediatr 2014;81:43-9.

24. Singhal A, Cole TJ, Fewtrell M, Deanfield J, Lucas A. Is slower early growth beneficial for long-term cardiovascular health? Circulation 2004;109:1108-13.

25. Leunissen RW, Kerkhof GF, Stijnen T, Hokken-Koelega A. Timing and tempo of first-year rapid growth in relation to cardiovascular and metabolic risk profile in early adulthood. JAMA 2009;301:2234-42.

26. Hovi P, Andersson S, Räikkönen K, et al. Ambulatory blood pressure in young adults with very low birth weight. J Pediatr 2010;156:54-59.e1.

27. Lapillonne A, Griffin IJ. Feeding preterm infants today for later metabolic and cardiovascular outcomes. J Pediatr 2013;162(3 Suppl):S7-16.

28. Ong KK, Langkamp M, Ranke MB, et al. Insulin-like growth factor I concentrations in infancy predict differential gains in body length and adiposity: the Cambridge Baby Growth Study. Am J Clin Nutr 2009; 90:156-61.

29. Madsen AL, Larnkjær A, Mølgaard C, Michaelsen KF. IGF-I and IGFBP-3 in healthy 9 month old infants from the SKOT cohort: breastfeeding, diet, and later obesity. Growth Horm IGF Res 2011;21:199-204.

30. Hernandez MI, Rossel K, Peña V, et al. Leptin and IGF-I/II during the first weeks of life determine body composition at 2 years in infants born with very low birth weight. J Pediatr Endocrinol Metab 2012;25:951-5.

31. Parkinson JR, Hyde MJ, Gale C, Santhakumaran S, Modi N. Preterm birth and the metabolic syndrome in adult life: a systematic review and metaanalysis. Pediatrics 2013;131:e1240-63.

32. Bikle DD, Wang Y. Insulin-like growth factor-I and bone. IBMS BoneKEy 2011;8:328-41.

33. Ali AT, Hochfeld WE, Myburgh R, Pepper MS. Adipocyte and adipogenesis. Eur J Cell Biol 2013;92:229-36.

34. Eliakim A, Nemet D, Ahmad I, et al. Growth factors, inflammatory cytokines and postnatal bone strength in preterm infants. J Pediatr Endocrinol Metab 2009;22:733-40.

35. van de Lagemaat M, Rotteveel J, van Weissenbruch MM, Lafeber HN. Small-for-gestational-age preterm-born infants already have lower bone mass during early infancy. Bone 2012; 51:441-6.

36. Fewtrell MS. Does early nutrition program later bone health in preterm infants? Am J Clin Nutr 2011;94(6 Suppl):1870S-3S.

37. Larnkjaer A, Ingstrup HK, Schack-Nielsen L, et al. Early programming of the IGF-I axis: negative association between IGF-I in infancy and late adolescence in a 17-year longitudinal follow-up study of healthy subjects. Growth Horm IGF Res 2009;19:82-6.

38. van Bunderen CC, Oosterwerff MM, van Schoor NM, Deeg DJ, Lips P, Drent ML. Serum IGF1, metabolic syndrome, and incident cardiovas- cular disease in older people: a population-based study. Eur J Endocrinol 2013;168:393-401.

39. Hansen-Pupp I, Hövel H, Löfqvist C, et al. Circulatory insulin-like growth factor-I and brain volumes in relation to neurodevelopmental outcome in very preterm infants. Pediatr Res 2013;74:564-9.

40. Euser AM, Finken MJ, Kharagjitsingh AV, et al. IGF1 promoter polymorphism and cranial growth in individuals born very preterm. Horm Res Paediatr 2011;76:27-34.

41. Hansen-Pupp I, Hövel H, Hellström A, et al. Postnatal decrease in circulating insulin-like growth factor-I and low brain volumes in very preterm infants. J Clin Endocrinol Metab 2011;96:1129-35.

42. Okuma C, Hernández MI, Rodríguez P, et al. Microstructural brain and multivoxel spectroscopy in very low birth weight infants related to insulinlike growth factor concentration and early growth. Horm Res Paediatr 2013;79:197-207.

43. Lin S, Fan LW, Rhodes PG, Cai Z. Intranasal administration of IGF-1 attenuates hypoxic-ischemic brain injury in neonatal rats. Exp Neurol 2009;217:361-70.

44. Pang Y, Campbell L, Zheng B, Fan L, Cai Z, Rhodes P. Lipopolysaccharideactivated microglia induce death of oligodendrocyte progenitor cells and impede their development. Neuroscience 2010;166:464-75.

45. Hellgren G, Han W, Wang X, et al. Safety aspects of longitudinal administration of IGF-I/IGFBP-3 complex in neonatal mice. Growth Horm IGF Res 2011;21:205-11.

46. Wang X, Hellgren G, Löfqvist C, et al. White matter damage after chronic subclinical inflammation in newborn mice. J Child Neurol 2009;24:1171-8.

47. Pang Y, Zheng B, Campbell LR, Fan LW, Cai Z, Rhodes PG. IGF-1 can either protect against or increase LPS-induced damage in the developing rat brain. Pediatr Res 2010;67:579-84.

48. Ley D, Hansen-Pupp I, Niklasson A, et al. Longitudinal infusion of a complex of insulin-like growth factor-I and IGF-binding protein-3 in five preterm infants: pharmacokinetics and short-term safety. Pediatr Res 2013;73:68-74.

49. Agostoni C, Buonocore G, Carnielli VP, et al.; ESPGHAN Committee on Nutrition. Enteral nutrient supply for preterm infants: commentary from the European Society of Paediatric Gastroenterology, Hepatology and Nutrition Committee on Nutrition. J Pediatr Gastroenterol Nutr 2010;50:85-91.

50. Koletzko B, Goulet O, Hunt J, Krohn K, Shamir R; Parenteral Nutrition Guidelines Working Group; European Society for Clinical Nutrition and Metabolism; European Society of Paediatric Gastroenterology, Hepatology and Nutrition (ESPGHAN); European Society of Paediatric Research (ESPR). 1. Guidelines on Paediatric Parenteral Nutrition of the European Society of Paediatric Gastroenterology, Hepatology and Nutrition (ESPGHAN) and the European Society for Clinical Nutrition and Metabolism (ESPEN), Supported by the European Society of Paediatric Research (ESPR). J Pediatr Gastroenterol Nutr 2005;41:Suppl 2:S1-87.

51. Yeung MY, Smyth JP. Nutritionally regulated hormonal factors in prolonged postnatal growth retardation and its associated adverse neurodevelopmental outcome in extreme prematurity. Biol Neonate 2003;84:1-23.

52. Hay WW, Thureen P. Protein for preterm infants: how much is needed? How much is enough? How much is too much? Pediatr Neonatol 2010;51:198-207.

53. Burattini I, Bellagamba MP, Spagnoli C, et al.; Marche Neonatal Network. Targeting 2.5 versus $4 \mathrm{~g} / \mathrm{kg} /$ day of amino acids for extremely low birth weight infants: a randomized clinical trial. J Pediatr 2013;163:1278-82.e1.

54. Yang S, Lee BS, Park HW, et al. Effect of high vs standard early parenteral amino acid supplementation on the growth outcomes in very low birth weight infants. JPEN J Parenter Enteral Nutr 2013;37:327-34.

55. Alan S, Atasay B, Cakir U, et al. An intention to achieve better postnatal in-hospital-growth for preterm infants: adjustable protein fortification of human milk. Early Hum Dev 2013;89:1017-23.

56. Cormack BE, Bloomfield FH. Increased protein intake decreases postnatal growth faltering in ELBW babies. Arch Dis Child Fetal Neonatal Ed 2013;98:F399-404.

57. Olsen IE, Harris CL, Lawson ML, Berseth CL. Higher protein intake improves length, not weight, $\mathrm{z}$ scores in preterm infants. J Pediatr Gastroenterol Nutr 2014;58:409-16. 
58. Stoltz Sjöström E, Öhlund I, Ahlsson F, et al. Nutrient intakes independently affect growth in extremely preterm infants: results from a population-based study. Acta Paediatr 2013;102:1067-74.

59. Peiler A, Woelfle J, Stutte S, Schreiner F, Bartmann P, Gohlke B. Postnatal nutrition in extremely low birth weight infants and its impact on growth until the age of 6 years. Acta Paediatr 2014;103:e61-8.

60. Scattolin S, Gaio P, Betto M, et al. Parenteral amino acid intakes: possible influences of higher intakes on growth and bone status in preterm infants. J Perinatol 2013;33:33-9.

61. Costa-Orvay JA, Figueras-Aloy J, Romera G, Closa-Monasterolo R, Carbonell-Estrany X. The effects of varying protein and energy intakes on the growth and body composition of very low birth weight infants. Nutr J 2011;10:140.

62. Amesz EM, Schaafsma A, Cranendonk A, Lafeber HN. Optimal growth and lower fat mass in preterm infants fed a protein-enriched postdischarge formula. J Pediatr Gastroenterol Nutr 2010;50:200-7.

63. Roggero P, Giannì ML, Amato O, et al. Growth and fat-free mass gain in preterm infants after discharge: a randomized controlled trial. Pediatrics 2012;130:e1215-21.

64. Embleton ND, Cooke RJ. Protein requirements in preterm infants: effect of different levels of protein intake on growth and body composition. Pediatr Res 2005;58:855-60.

65. van den Akker CH, te Braake FW, Rövekamp-Abels WW, van Goudoever JB. Quality of amino acid solutions for preterm infants. Pediatrics 2008;121:865-6; author reply 866.

66. Ergenekon E, Hirfanonulllu I, Soysal S, et al. Physical and mental developmental effects of additional enteral protein supplementation in preterm newborns. Early Hum Dev 2010;86:Suppl 1:S85-6.

67. Morgan C, McGowan P, Herwitker S, Hart AE, Turner MA. Postnatal head growth in preterm infants: a randomized controlled parenteral nutrition study. Pediatrics 2014;133:e120-8.

68. Stutte S, Peiler A, Schreiner F, Bartmann P, Woelfle J, Gohlke B. Is postnatal nutrition associated with growth parameters until at the age of 6 years in infants born with extremely low birth weight? Horm Res Paediatr 2010;74:32.

69. Young L, Morgan J, McCormick FM, McGuire W. Nutrient-enriched formula versus standard term formula for preterm infants following hospital discharge. Cochrane Database Syst Rev 2012;3:CD004696.

70. Young L, Embleton ND, McCormick FM, McGuire W. Multinutrient fortification of human breast milk for preterm infants following hospital discharge. Cochrane Database Syst Rev 2013;2:CD004866.

71. Stephens BE, Walden RV, Gargus RA, et al. First-week protein and energy intakes are associated with 18-month developmental outcomes in extremely low birth weight infants. Pediatrics 2009;123:1337-43.
72. Cormack BE, Bloomfield FH, Dezoete A, Kuschel CA. Does more protein in the first week of life change outcomes for very low birthweight babies? J Paediatr Child Health 2011;47:898-903.

73. Biasini A, Marvulli L, Neri E, China M, Stella M, Monti F. Growth and neurological outcome in ELBW preterms fed with human milk and extraprotein supplementation as routine practice: do we need further evidence? J Matern Fetal Neonatal Med 2012;25:Suppl 4:72-4.

74. Pfister KM, Gray HL, Miller NC, Demerath EW, Georgieff MK, Ramel SE. Exploratory study of the relationship of fat-free mass to speed of brain processing in preterm infants. Pediatr Res 2013;74:576-83.

75. Vucetic Z, Totoki K, Schoch H, et al. Early life protein restriction alters dopamine circuitry. Neuroscience 2010;168:359-70.

76. Isaacs EB, Gadian DG, Sabatini S, et al. The effect of early human diet on caudate volumes and IQ. Pediatr Res 2008;63:308-14.

77. Choi S, Disilvio B, Fernstrom MH, Fernstrom JD. Meal ingestion, amino acids and brain neurotransmitters: effects of dietary protein source on serotonin and catecholamine synthesis rates. Physiol Behav 2009;98: $156-62$.

78. de Kieviet JF, Oosterlaan J, Vermeulen RJ, Pouwels PJ, Lafeber HN, van Elburg RM. Effects of glutamine on brain development in very preterm children at school age. Pediatrics 2012;130:e1121-7.

79. Larnkjær A, Mølgaard C, Michaelsen KF. Early nutrition impact on the insulin-like growth factor axis and later health consequences. Curr Opin Clin Nutr Metab Care 2012;15:285-92.

80. Ohkawa N, Shoji H, Kitamura T, et al. IGF-I, leptin and active ghrelin levels in very low birth weight infants during the first 8 weeks of life. Acta Paediatr 2010;99:37-41.

81. Wang XL, Ge MR, Wu WY, Zhang J. [Insulin-like growth factor 1 levels and their association with growth and development in infants aged 1-24 months]. Zhongguo Dang Dai Er Ke Za Zhi 2010;12:459-61.

82. Iñiguez $\mathrm{G}$, Ong $\mathrm{K}$, Bazaes $\mathrm{R}$, et al. Longitudinal changes in insulin-like growth factor-I, insulin sensitivity, and secretion from birth to age three years in small-for-gestational-age children. J Clin Endocrinol Metab 2006;91:4645-9.

83. Hyun SE, Lee BC, Suh BK, et al. Reference values for serum levels of insulin-like growth factor-I and insulin-like growth factor binding protein-3 in Korean children and adolescents. Clin Biochem 2012;45:16-21.

84. Embleton NE, Pang N, Cooke RJ. Postnatal malnutrition and growth retardation: an inevitable consequence of current recommendations in preterm infants? Pediatrics 2001;107:270-3.

85. Senterre T, Rigo J. Reduction in postnatal cumulative nutritional deficit and improvement of growth in extremely preterm infants. Acta Paediatr 2012;101:e64-70. 